\title{
Politics, cultural heterogeneity and support for European Union membership in Turkey
}

\section{F. Michael Wuthrich , M. Murat Ardağ \& Deniz Uğur}

To cite this article: F. Michael Wuthrich , M. Murat Ardağ \& Deniz Uğur (2012) Politics, cultural heterogeneity and support for European Union membership in Turkey, Southeast European and Black Sea Studies, 12:1, 45-62, DOI: 10.1080/14683857.2012.661221

To link to this article: http://dx.doi.org/10.1080/14683857.2012.661221

\section{曲 Published online: 13 Mar 2012.}

Submit your article to this journal $\pi$

Llll Article views: 390

Q View related articles $₫$ 


\title{
Politics, cultural heterogeneity and support for European Union membership in Turkey
}

\author{
F. Michael Wuthrich ${ }^{\mathrm{a} *}$, M. Murat Ardağ ${ }^{\mathrm{b}}$ and Deniz Uğur ${ }^{\mathrm{b}}$ \\ ${ }^{a}$ University of Kansas, Lawrence, KS, USA; ${ }^{b}$ Bilkent University, Ankara, Turkey
}

(Received 21 April 2011; final version received 28 September 2011)

\begin{abstract}
This study analyses factors related to attitudes toward European Union (EU) accession, taking into account political affiliation, religious and ethnic identity, fear of foreign threat, utilitarian considerations, along with a number of other variables through a survey conducted among Turkish citizens in general and also among various Alevi communities. The results show that Alevi identity, in contrast to Kurdish background, was strongly indicative of positive attitudes toward the EU. Furthermore, in conjunction with existing literature on EU integration, political party affiliation, utilitarian concerns and fear of foreigners were associated with attitudes toward membership among all groups, while religiosity was not a significant determinant of attitudes toward the EU.
\end{abstract}

Keywords: Turkey; European Union; public opinion; Alevis; Kurds; political cueing

What determines social support for European Union (EU) membership in Turkey? As the successor of a multi-religious, multi-ethnic empire, the Republic of Turkey, under the guidance of the Kemalist modernization project, has always been a country officially pointed toward the west. Mustafa Kemal Atatürk's well-known ambition for the fledgling Republic, 'Reaching the level of contemporary civilizations', is still conceived as a relevant project for Turkey today. Although membership in the EU is certainly only one possible interpretation or manifestation of this ambition, the relationship of the former with the latter is not missed on the Turkish population as a whole. However, an important issue as this heterogeneous nation continues negotiations with the EU, itself a complex and heterogeneous body, is what determinants influence the groundswell of support for or against EU membership among Turkish citizens. Addressing the broader literature on EU integration in general, this small study, based on a unique survey conducted in late spring and early summer of 2009, takes into account the targeted variables in the literature with a special focus on the impact of political party cueing and non-dominant cultural status in determining one's attitudinal position toward the EU. To discuss the latter, particular emphasis was made to include within the sample the religiously distinct Alevis, which comprise somewhere in the range of $10-25 \%$ of the population (Poyraz 2005, 503), and citizens of Kurdish language background, also constituting between 15 and $20 \%$ of the population (Heper 2007, 1). ${ }^{1}$

*Corresponding author. Email: mwuthrich@ku.edu 
Measuring the relationship between social support and affiliation to political parties in the Turkish case seems both a critical endeavour to understand the negotiation process and an issue that has been underexplored through quantitative means. While EU membership remained at the level of a theoretical or macro project, what society at large thought about EU accession seemed not to be of great concern by the political elites, and the leaders of the mainstream parties generally favoured a westward focus. Since acceptance of candidacy in 1999 and particularly since negotiations have formally commenced in 2005 (Y1lmaz 2011), the nitty-gritty details of reform that touch on sensitive social issues have given political opponents opportunity to create social discomfort toward the idea of EU accession and its 'impositions' on the national status quo. ${ }^{2}$ Thus, it is important to consider how changes in domestic politics and competition among political elites might impact attitudes toward the EU. At this stage of EU-Turkey relations, it is hard not to see a connection between domestic politics, social attitudes and possibilities for advancement in the EU negotiation process.

Furthermore, considering all the other intervening factors, how does one's identity impact one's orientation toward EU accession, including a strong affiliation with one's country and/or identification with a non-dominant cultural or religious community, ${ }^{3}$ such as the Kurds or Alevis? Does simply identifying with any non-dominant group result in the same attitudinal outcome in this regard? During the process of accession, of course, these groups' status and relationship with the State could have ramifications in Turkey's EU membership process and the accompanying democratization process. For the last 20 years, Turkey has been struggling with internal and external affairs simultaneously, which have often been significantly intertwined. It has had to improve its democracy on various levels to stay on course with the EU; while doing so, it has had to face the question of granting wider cultural and political rights to various ethnic, religious, cultural groups within the population as the EU has observed the developments closely and, at times, critically (Grigoriadis 2009; Ulusoy 2009). How these groups, thus, approach the prospect of EU membership and its consequences seems of interest.

This paper intends to bring the broader comparative literature on Europeanization to bear on determinants of support for EU membership in Turkey, a process initiated by Kentmen's (2008) excellent article, which was nonetheless unable, based on existing data, to address the question of political affiliation and cultural minorities. ${ }^{4}$ In the following sections of this paper, we provide a brief outline of Alevis and Kurds and their relations with the State and also the nature of domestic politics in Turkey. Then we will consider this in light of the literature regarding the EU, Europeanization and public attitudes in order to derive a number of hypotheses. Following this, our survey and the research model will be discussed and the results from the data will be presented. Finally, we will analyse the data and discuss where this might lead future research on this topic.

\section{Alevis, Kurds and politics in Turkey}

The Alevis are a heterodox religio-cultural community united by their veneration of the Turkish dervish, Hac1 Bektaş who lived in the thirteenth century. ${ }^{5}$ His followers diverged into two different communities in the Ottoman Empire - Bektaşi and Kızılbaş/Alevi - but, rightly or wrongly, in modern parlance, these groups have generally been discussed as one community under the umbrella term 'Alevi' 6 
(Melikoff 2003, 2). While they indeed share certain beliefs with Shiites, including the veneration of Caliph Ali and the twelve Imams, their religious and cultural practices have been distinctly shaped by their Anatolian roots. Alevis have had a complex relationship with the Governments of Anatolia for hundreds of years. In interviews with leaders of a number of Alevi communities in Istanbul, each of which having distinguishing characteristics from the others, all of them, of their own accord, brought up the claim that troubles between Alevis and other Muslims began with the reign of Sultan Selim, the First (1512-1520), ${ }^{7}$ who according to their accounts, brought in Sunni clerics from Egypt and began to impose Sunni orthodoxy on the Anatolian populace, clamping down harshly on Alevis and others with 'non-orthodox' belief systems (Goodwin 1998, 91). Many Ottoman leaders like Selim assumed that Alevis were always potential supporters of the Shiite Safavids in Persia, and the term 'kızılbaș' - literally 'red head/top' - referred to the red turbans worn by those who apparently fought with the Safavids against the Ottoman Porte (Shankland 2003, 19). The Bektaşi were generally closely tied to the janissaries of the Ottoman State and, thus, were largely in a favourable position until Mahmud II abolished the janissary corps and officially closed down the Bektaşi order in 1826 (Goodwin 1998, 298). Ottoman history indicates well that the manner in which the State has defined and perceived Alevis has had important consequences - one designation set them as a threat to the State, the other as largely harmless or allied with the State.

Kurds, on the other hand, have historically been a collection of peoples that have lived in the mountainous borderland that historically separated the Ottoman Empire from and Safavids with Kurdish tribes occupying both sides of the divide. ${ }^{8}$ For the most part, these various tribal leaders were loyal to their patron-state as long as they were given autonomy and allowed to maintain their existing sociopolitical structures (Heper 2007). With the fall of the Ottoman Empire and the division of the Middle East after the First World War, Kurdish tribes found themselves divided across Turkey, Iran, Iraq and Syria, with the largest segment falling within the boundaries of the modern Turkish Republic. Throughout Ottoman and Early Republic history, one can find numerous tribes that supported or rebelled against the Porte/State, often in opposition to one another, and with rebellions usually occurring in response to encroachment and loss of autonomy in relation to the Porte/State. While the imagined community of a Kurdish nation might have existed in the minds of certain Kurdish elites and intellectuals for some time (along with many European and American supporters who could easily envision a Kurdish nationalist ideal), the actual evidence in Turkey of a grassroots 'national' Kurdish identity, in its modern conceptualization, has largely been a post-1980 coup phenomenon.

During the 'nation-creating' process led by Mustafa Kemal Atatürk and the group of elites who founded the Republic of Turkey, ${ }^{9}$ there were various invitations, exclusions, inclusions, assimilations, integrations among the various segmented groups (Kadığlu 1996; Çağaptay 2002). Within such a framework, Alevis and Kurds in particular were often seen as 'borderline' groups in terms of national identification in the eyes of the State. A significant majority of Alevis, though certainly not Sunni Muslim - a potential problem even for the secularists to the extent that it was seen as obstacle to homogenization - were, at least, largely Turkish speaking. Kurds were also a borderline group, especially those that refused to part with their native language dialects and sociocultural practices, inhibiting effective 
centralization of the State in areas where this group predominated; on the other hand, their long history of living side by side with Turks and a shared Sunni brotherhood encouraged the hope that they might eventually fuse as one within a Turkish nation (Yeğen 2009).

Ultimately, which side of the border these groups ended up in the conceptualization of the 'nation' depended on the apparent emphasis of the State on issues of language and religion. Due to the unique nature of each of these large cultural groups, their fortunes with the State - at least their fortunes as perceived by many members of these two groups - often rose and fell in inverse relation to one another. While Kemalists had firm control of the State, they were viewed with favour by Alevis and relations were largely harmonious. To the extent that a unified language and culture and a centralized State were emphasized, the State was often at odds with Kurdish citizens. During periods where Islamists, like those in the National Outlook (Milli Görüss) movement primarily led by Necmettin Erbakan, had greater influence in politics, they seemed to forge stronger connections with Sunni Kurds, while Alevis (and certainly also Kurdish Alevis) viewed them with suspicion. ${ }^{10}$

The political participation of these groups at the national level has demonstrated both similarities and divergence. A common claim about Alevis and politics is that they support the Republican People's Party (Cumhuriyet Halk Partisi [CHP]) in large numbers because of their long-observed love for the Republican reforms and for Mustafa Kemal Atatürk, the founder of the Turkish Republic, the legacy of whom continues in the party he founded, the CHP. The evidence for this is that during the first three decades of the multiparty system (1950-1980), the CHP's strongest centre of support existed in the eastern region of the country, which has historically been densely populated by Alevis. Shankland $(2003,21)$ has also observed the love Alevis have for Atatürk and his principles, and these, particularly through the establishment of secularism, offered Alevis protection from religious persecution. Erman and Göker $(2000,111)$ point out the emphasis in more recent history that one of the largest Alevi associations, Cem Vakfi, places on Kemalism and the Republican ideals. Though some Alevis experimented with the formation of a political party that would be sympathetic to Alevis in the late 1960s and through the 1970s (the Unity Party) and their historical sympathies toward socialist and communist parties have been noted (Aringberg-Laanatza 2003; Shankland 2003). They are believed to be one of the communities that have faithfully supported Atatürk's party (CHP) in large numbers (Çarkoğlu 2005; Grigoriadis 2006).

Kurdish voters, on the other hand, have been notoriously volatile when it comes to national elections and party affiliation largely due to mobilization through local tribal leaders, large landowners and religious authorities who frequently switched their allegiance, particularly during the pre-1980 period (Grigoriadis 2006, 450). While Kurds initially voted for the CHP in large numbers in the southeast, by the 1970s, it was the region providing the least support for this party. Throughout the first decades of the multiparty system in Turkey, the southeast region was associated with the highest levels of electoral volatility and independent candidates (Dorronsoro and Watts 2009; Wuthrich 2011). Following the 1980 military coup and the return to politics in 1983, Kurdish voters tended to fall into two general tendencies. One segment of the Kurdish electorate tended to respond favourably to parties with religious-conservative appeal or those who had strong ties to Sufi religious orders among Kurds (Yalçın-Heckmann 1990; Duran 1998). Another significant population of Kurds in the southeast have supported pluralist, social justice parties on the 
'political left'. In the 1980s, this segment of support gravitated to the successor to the CHP, which was closed down during the military regime in 1981, the Social Democratic Populist Party (Sosyaldemokrat Halkçı Parti [SHP]). The Kurdish leftist political leadership mobilizing this electorate among Kurds ultimately broke off and founded their own party, the People's Labour Party, which initially formed an election coalition with SHP in 1991 but ran independently as a succession of parties or in electoral coalition with other minor leftist parties from 1995 onward. ${ }^{11}$ Particularly since 2002, these two political tendencies have increasingly began to manifest themselves as a regional two-party system in which the current governing Justice and Development Party (Adalet ve Kalkınma Partisi [AKP]) competes in close contest with the contemporary manifestation of the Kurdish leftish-nationalist party (currently the Peace and Democracy Party (Barış ve Demokrasi Partisi [BDP]), but at the time of the survey (2009), the Democratic Society Party (Demokratik Toplum Partisi [DTP])) (Wuthrich 2011, 352).

In the general elections of 2002, a clean sweep was made of all incumbent parties in parliament, thanks in part to the $10 \%$ national electoral threshold, and two parties entered the Grand National Assembly on pro-EU party platforms, though these were modestly expressed (Çarkoğlu 2003a, 248). The attitude toward EU membership among the electoral support for these two parties was very different. As can be seen by the survey results presented in Çarkoğlu's $(2003 \mathrm{~b}, 174)$ study, while the CHP voters showed one of the highest levels of support for the EU $(79 \%)$, the supporters of the AKP showed one of the lowest levels of support (53\%), second only to the explicitly religiously oriented Felicity Party. Following the election, however, the AKP, which has been portrayed particularly by the CHP's grassroot secular-nationalist supporters as a serious threat to Turkish secularism, attempted to legitimize itself, at least in part, by whole-heartedly embracing the EU and the reforms needed to speed up the process of accession. Within the socially-polarized environment, similar approval and support by the CHP for the EU project could be seen as a legitimization of their arch-rival; therefore, the party's stance toward EU negotiations grew continually sour, suggesting that EU reforms were simply a pretext to establish the conditions for an Islamist transformation of the secularist State (Gülmez 2008; Y11maz 2011, 12). Such a domestic context allows us to investigate the nature of the relationship between political affiliation and support for EU membership.

In Çarkoğlu's (2003b) study, arguably due to a mismatch of variables in his regression model, no political party affiliation was associated with significant support or antagonism toward EU membership although the coefficient for CHP affiliation was modestly positive while AKP and Kurdish leftist-nationalist party affiliation was modestly negative. A later similar study by Çarkoğlu (2004), again with a mismatched model and no significant coefficient, showed a positive coefficient for support for the EU among AKP supporters and the CHP, and a negative coefficient again for the Kurdish leftist-nationalist party. Though these results cannot be taken with any certainty, they pose interesting questions in light of the broader comparative literature in regard to public opinion, politics and EU integration which will be discussed briefly below.

\section{Public opinion and the EU}

Within the broader comparative literature, there is a significant body of work covering attitudes toward the EU and European integration in general, offering a 
potentially powerful roadmap to help set the framework for a study seeking to learn the determinants of support among Turkish citizens.

These studies of public opinion toward the EU and the integration process have largely come to focus on three major factors: utilitarian considerations, national identity and political affiliation. A number of studies address utilitarian and economic concerns as one of the primary independent variables. For example, Gabel (1998) addressed five theories for support for European integration related to age, income, occupation, partisanship and political values and found that utilitarian economic concerns were the primary factor in determining how one felt about the integration process. A more recent study by Garry and Tilley (2009) argues that economic factors condition the salience of identity as a determinant. In a study by Hooghe and Marks (2005), the authors found that economic utilitarian concerns were one of the significant determinants of support for integration along with identity and the effects of political party cueing. In a single country studying factors affecting how the Swiss public views the EU, Christin and Trechsel (2002) investigate how economic and social concerns might negatively influence one's attitude toward joining the EU. The fears of economic harm caused by joining the EU had a significant and strong impact on Swiss attitudes. Importantly, in a work on Turkey by Kentmen (2008), one of the rare studies on Turkish attitudes toward the EU addressing the comparative public opinion literature, 'perceived economic prospects' of membership was found to be the strongest indicator of attitudes toward the EU among Turkish citizens. Furthermore, at the national level in Turkey, Kalaycioğlu (2008) found that 'expression of economic satisfaction' was a significant determiner of party affiliation in every case and the most significant factor determining affiliation of those who support the current governing party, the AKP. These studies, both in the literature in general and in the study of Turkey as a specific case, indicate that economic and social utilitarian concerns would be critical variables to test in further studies. From the studies above, we derive the following hypothesis regarding the attitude of citizens in general toward the EU based on these concerns:

H1: Utilitarian considerations will be a significant factor determining the attitudes of Turkish citizens toward EU membership.

Beyond cost/benefit analyses that influence public attitudes toward the EU, a second factor extensively studied is national identity. A number of studies mentioned above also demonstrated the importance of national identity in shaping public attitudes about the EU. Hooghe and Marks (2005) showed that an exclusive national identity was the strongest factor at work among the other significant variables, being negatively related to support for integration. Christin and Trechsel (2002) also showed feelings of national identity to have a negative effect on Swiss opinion regarding the EU. Kentmen (2008), in her research related to Turkish public opinion and EU membership, also demonstrated a negative interaction between national identity and ideas about the EU. Furthermore, regarding religious identity, she determined that religiosity was not a significant factor at all in attitudes toward accession. This contrasts Çarkoğlu's $(2003 \mathrm{~b}, 185,2004,38)$ studies which consistently showed religiosity as a negatively-regressed determinant of EU support.

Two other studies looking at the impact of national identity on the EU should also be examined. McLaren (2002) took the variables used in Gabel's (1998) analysis and added another variable to the model - fear of others. Utilizing Eurobarometer 
data related to attitudes toward immigrants, she measured the effects of this perception of cultural threat in relation to support for EU integration. The results showed that fear of others indeed impacted public opinion toward the EU negatively. Another study by Carey (2002) divided national identity into three separate strands, intense feelings for one's country, attachment toward the nation and territorial entities and the threat of other people or cultures encroaching on the nation. He analyses them in separate models, but each type of feeling towards one's nationality significantly affected one's view of EU integration. In addition and particularly relevant to the question of Alevi support, he determined that ethnicities in a minority position in a society viewed integration more positively than those of the ethnic majority.

The existing research on the EU and national identity draw us to a number of points relevant to Turkey. We broke down national identity into two strands, intense feelings for one's country (patriotism) and fear of foreign threat. A further point for consideration is the attitudes of non-dominant cultural groups like Alevis and Kurds toward the EU. We present the following hypotheses:

H2: Strong feelings of national sentiment will negatively affect the support of Turkish citizens for EU membership.

H3: Fear of outsiders will coincide with negative attitudes toward Turkey's EU accession.

H4: Identification with a non-dominant cultural group, such as an Alevis or Kurds, will be a positive determinant of support for the EU.

The final factor of note in the literature regarding public opinion toward the EU and European integration is political affiliation. Gabel's (1998) study showed the importance of partisanship in determining support for EU integration. Recently, a number of scholars have studied whether the affiliation with party effect was primarily a top-down or bottom-up issue. In other words, did public opinion entice parties to behave a certain way toward Europe or was it party 'cueing' that shaped public views toward the EU? Hooghe and Marks (2005) show 'cueing' to be significant though they do not clearly demonstrate that their measurement comes absolutely from top-down processes. Ray (2003) argues that cueing takes place but that it is also conditioned by a number of factors. When a party is not unified within itself, its effects on the public are reduced. However, disagreement in views about Europe across parties increases the power of party cueing. Furthermore, an individual's level of attachment with the party affects the influence a party has to be able to cue that person. Research has also shown (Steenbergen, Edwards, and de Vries 2007) that a party divided amongst itself leads to a divided constituency, a proposition also held by Gabel and Scheve (2007). They also acknowledge certain conditions where public opinion could cue the parties.

Finally, several other studies of political effects on public opinion regarding the EU are also relevant to the Turkish and Alevi case. Mattila and Raunio (2006) claim that the power of parties to affect public opinion is stronger in smaller, politically non-central parties. Furthermore, the strength of parties to affect the populace is greater in newly emerging countries where membership is a relevant issue. In another study, Jolly (2007) provides data to show that regional parties are more supportive of EU integration than national parties. Although Kentmen (2008) did not have the data 
to measure party affiliation and support for the EU in her study, in other research conducted in Turkey in 2002, Çarkoğlu (2003b, 2004) did not find party affiliation to be a significant indicator in those particular analyses (though the coefficient was negative in both cases), but his descriptive data and personal analysis suggested that support for the EU might be significantly related to support for the now defunct Halkin Demokrasi Partisi (HADEP), which is a de facto regional party largely seen to have been serving the interests of Kurdish leftist-nationalists.

The research above points to a prediction that political party affiliation will be a salient determiner of one's attitude toward EU membership in Turkey. As parties have varying stances toward the EU - although it is also true that no party rejects the EU outright - we could assume that partisanship might play a role. As noted previously, the AKP party leadership strongly advocates accession to the EU and the negotiation process; the CHP, however, though strongly supporting membership with the EU in the past has become much more ambivalent in their stance toward the EU. The nationalist party, Milliyetçi Hareket Partisi (MHP), has also remained ambivalent to negative toward the accession process. In Turkey, the only truly regional party of note at the time that the survey was conducted was the Democratic Society Party (DTP), ${ }^{12}$ which is supported by Kurdish leftist-nationalists in the southeast. With these considerations in mind, we form the following hypotheses:

H5: Affiliation to the CHP will not be significantly indicative of an attitude toward the EU.

H6: Supporters of the DTP will also support membership in the EU.

H7: Those who support the AKP will have positive attitudes about the EU.

H8: Supporters of the MHP will not support EU membership.

\section{Method and data}

In order to examine how attitudes among Alevis toward EU membership might be affected, we created and conducted a survey with items addressing the issues above along with a number of control variables. In order to ensure a sample that included the views of Alevis and Kurds, we had to address a number of challenges. In research in Turkey, it is not permissible to ask one's ethnic identity or first language directly. The closest proxy is asking them the language their mother spoke at home. There are a number of problems with this. Many Turkish citizens who consider themselves ethnically Kurdish do not speak Kurdish well or at all. There are also those whose fathers speak Kurdish and have inherited a strong Kurdish identity but who are not able to identify themselves through the question. Thus, it is likely that not all Kurds participating in the survey were detected through the variable, and so the proxy leads to a level of 'blurriness' in measuring opinions among citizens of Kurdish origin.

Some Alevis, as has been noted in other studies such as Çarkoğlu (2005), have been notoriously evasive in volunteering their Alevi identity in previous research. Thus, in order to access Alevi opinion with certainty and ensure some variety within the Alevi community among the respondents, we distributed the surveys through four large Alevi associations with divergent views and practices from one another, Cem Vakfi, Hacı Bektaş Vakfi, Pir Sultan Abdal Kültür Derneği and Ehli Beyt Vakfi. In each case, we discussed our study with the director of the associa- 
tion, explaining our research plan and obtaining consent and assistance in distribution. The surveys were distributed at a subsequent meeting or cem ceremony or taken home and distributed among family members and Alevi friends, and we returned later to pick up those completed.

Although resources were not available for a precisely random or representative national sample, 340 surveys were distributed among the general populace in several cities and communities with the intent to sufficiently cover all the independent variables. The surveys were conducted between late April and early July 2009. During this period, there was no particularly salient issue regarding the EU on the national news agenda. By the end of July and the beginning of August, the discussion of a 'Kurdish initiative' ensued, and its association with EU reforms certainly polarized public opinion in this regard, but the survey data were collected prior to these developments. The net result of our survey distribution and gathering method was 490 completed surveys, including 150 surveys by Alevis and 78 by those whose mother spoke a dialect of Kurdish with overlap between these two groups.

For all the models, ordered logit regression was utilized through the statistical package, STATA 9.1. The dependent variable, I strongly support Turkey's entrance into the European Union, was coded 1 to 5 on an ordinal scale including 'strongly agree' and 'strongly disagree'. The independent variables derived from the hypotheses above were operationalized in the following ways. To measure utilitarian political behavior, we gave two sets of statements, one relating to economic concerns and the other to the solving of social problems. Respondents were asked to agree or disagree, again on a 1 to 5 scale, as to the following two economically-focused statements:

A political party's most important duty is to look after the economic benefit of his/her fellow citizens.

In the elections, I give my vote to the party with the best economic plan for the country.

The variables were converted to an index by taking a simple average of the two. A nearly identical set was given related to addressing current social problems in the country, and the same type of index was created for these. An index of the combined utility score (social and economic) was calculated.

In order to get a measure for strong national sentiment (patriotism), respondents were presented with the following statements on a 1 to 5 scale:

A Turk's only friend is another Turk.

Love it (Turkey) or leave it.

When I see the Turkish flag, I feel happy.

These questions have also been used for indexes of nationalism in other studies in Turkey (Çarkoğlu 2006), but, outside the first statement, seem to fall more in the category of a type of patriotism or strong feelings of national identity as demarcated by Carey (2002). A simple average was calculated and used as a 'feelings of national identity' index. Beyond these questions, we also included a couple of items that addressed the fear of encroachment by foreigners along a 1 to 5 scale: 
Foreigners residing in our country harm our culture.

Foreigners residing in our country make it harder to find jobs.

The average of these statements on a 1 to 5 scale, also used in Çarkoğlu's study (2006), was taken as the index for this issue of fear of foreign threat.

In determining political affiliation, we chose to focus on the five or six political parties that were represented well enough within our survey sample to be considered. The parties currently in the Grand National Assembly - i.e. the AKP, the CHP, the Nationalist Action Party (MHP) and the DTP ${ }^{13}$ - were taken into account. Due to its popularity among Alevis, the communist Türkiye Komünist Partisi (TKP) was also included. ${ }^{14}$ The ultra-nationalist MHP had only one supporter among the 150 Alevis measured but had plenty of support among the general population that was surveyed. With each of these parties, we created a graduated scale of affiliation based on responses to five items. The first three were a vote for the party in the 2007 general election, the 2009 local election and their hypothetical vote for a party if they had to vote today. The last two items required agreement to the following statements:

My party choice will never change.

I feel closely connected to my party.

To create the index for affiliation, each positive response equalled a point on a 0 to 5 scale.

To control for other possible independent variables besides mother's language at home, items related to gender, place of longest residence (village, town, city, overseas and mixed) strength of religion as a source for views, education, income and age were included in the survey.

\section{Results}

A perusal of the results in Table 1 confirms a number of our hypotheses set out above while disconfirming others. Model 1 was conducted with the entire survey sample. In measuring the variables against support for EU membership with the entire survey set, several results of significance appeared. The dummy variable identifying the participant as Alevi turned out to be the most significant indicator for EU support, followed by the aggregate variable measuring social and economic utilitarian concerns. Income level also turned out to be mildly indicative for this model. In terms of political affiliation, support for the AKP and DTP was a moderate indicator of support for the EU while support for the communist party (TKP) was related with negative attitudes toward EU membership. The supporters of MHP, the nationalist party, in this model, had a negative coefficient approaching significance, but the result is not as clear in the first model as in the second model with only non-Alevis. Additionally, the fear of foreigners was negatively associated with support for accession. The party of Atatürk, the CHP, did not have a significant score for EU support in this model.

In Model 2, only non-Alevi participants were measured for EU support. Among this group, support for the TKP was again negatively regressed against support for 
Table 1. Ordered logit regression results.

\begin{tabular}{|c|c|c|c|}
\hline & $\begin{array}{c}\text { Model } 1 \\
\text { Total } \\
(O=361)\end{array}$ & $\begin{array}{l}\text { Model } 2 \\
\text { Non-Alevi } \\
(O=276)\end{array}$ & $\begin{array}{c}\text { Model } 3 \\
\text { Alevi } \\
(O=142)\end{array}$ \\
\hline Dependent variable $\boldsymbol{}$ & \multicolumn{2}{|c|}{ Support for the EU } & \\
\hline $\begin{array}{l}\text { Predictors V } \\
\text { Age }\end{array}$ & $016^{*}$ & $013^{\mathrm{a}}$ & 001 \\
\hline & $\begin{array}{l}.010 \\
(.008)\end{array}$ & $(.009)$ & (.019) \\
\hline Gender & .220 & $.382^{\mathrm{a}}$ & -.196 \\
\hline & $(.210)$ & $(.223)$ & $(.382)$ \\
\hline Mother's language - Turkish & -1.272 & -.576 & -.726 \\
\hline & $(.745)$ & $(1.16)$ & $(.702)$ \\
\hline Mother's language - Kurdish & $\begin{array}{l}-.727 \\
(.742)\end{array}$ & $\begin{array}{r}.861 \\
(1.23)\end{array}$ & $\begin{array}{l}-.989 \\
(.712)\end{array}$ \\
\hline Alevi & $\begin{array}{l}1.015^{* * *} \\
(.317)\end{array}$ & - & - \\
\hline City dweller & $\begin{array}{l}.310 \\
(.329)\end{array}$ & $\begin{array}{l}.340 \\
(.466)\end{array}$ & $\begin{array}{l}.049 \\
(.493)\end{array}$ \\
\hline Village dweller & $\begin{array}{l}.622 \\
(484)\end{array}$ & $\begin{array}{l}.337 \\
(472)\end{array}$ & $\begin{array}{l}.797 \\
(.649)\end{array}$ \\
\hline Income & $241^{*}$ & $.217^{\mathrm{a}}$ & .114 \\
\hline Education & $\begin{array}{l}(.116) \\
.038 \\
(.120)\end{array}$ & $\begin{array}{l}(.113) \\
.046 \\
(.154)\end{array}$ & $\begin{array}{c}(.162) \\
-.067 \\
(.185)\end{array}$ \\
\hline Support EU membership & - & - & - \\
\hline AKP supporter & $\begin{array}{l}.335^{* *} \\
(.123)\end{array}$ & $\begin{array}{l}.165^{\mathrm{a}} \\
(.113)\end{array}$ & $\begin{array}{l}1.308^{* * *} \\
(.409)\end{array}$ \\
\hline CHP supporter & $\begin{array}{l}.016 \\
(.079)\end{array}$ & $\begin{array}{l}-.128^{\mathrm{a}} \\
(.086)\end{array}$ & $\begin{array}{l}.313^{*} \\
(.144)\end{array}$ \\
\hline MHP supporter & $\begin{array}{l}-.198 \\
(.126)\end{array}$ & $\begin{array}{l}-.369^{* *} \\
(.119)\end{array}$ & - \\
\hline DTP supporter & $\begin{array}{l}.327^{*} \\
(.141)\end{array}$ & $\begin{array}{l}-.274 \\
(.275)\end{array}$ & $\begin{array}{l}.787^{* * *} \\
(.202)\end{array}$ \\
\hline TKP supporter & $\begin{array}{l}-.491^{* * *} \\
(.150)\end{array}$ & $\begin{array}{l}-.746^{* * *} \\
(.179)\end{array}$ & $\begin{array}{l}.019 \\
(.191)\end{array}$ \\
\hline Views come from beliefs & $\begin{array}{l}-.047 \\
(.108)\end{array}$ & $\begin{array}{l}-.104 \\
(.122)\end{array}$ & $\begin{array}{l}.060 \\
(.189)\end{array}$ \\
\hline Feelings of national identity & $\begin{array}{l}-.076 \\
(.137)\end{array}$ & $\begin{array}{l}-.156 \\
(.142)\end{array}$ & $\begin{array}{l}-.165 \\
(.235)\end{array}$ \\
\hline Foreign threat & $\begin{array}{l}-.345^{*} \\
(.151)\end{array}$ & $\begin{array}{l}-.207 \\
(.155)\end{array}$ & $\begin{array}{r}-.555^{*} \\
(.265)\end{array}$ \\
\hline Utility aggregate & $\begin{array}{l}.507^{* *} \\
(.166)\end{array}$ & $\begin{array}{l}.475^{* *} \\
(.162)\end{array}$ & $\begin{array}{l}1.207^{* * *} \\
(.323)\end{array}$ \\
\hline Left-right ideological scale & $\begin{array}{l}.035 \\
(.116)\end{array}$ & $\begin{array}{l}.155 \\
(.090)\end{array}$ & $\begin{array}{l}-.003 \\
(.178)\end{array}$ \\
\hline Pseudo $R^{2}$ & .107 & .090 & .151 \\
\hline
\end{tabular}

Notes: Stata 9.1 was used in this research. ${ }^{*}$ Significant at $<.05$ level. ${ }^{* *}$ Significant at $<.01$ level. ${ }^{* *}$ Significant at a $<.001$ level.

${ }^{a}$ Approaching significance $>.05<.15$.

the EU and a negative coefficient for support for the nationalist MHP became significant. Although support for the AKP approached significance in its support for the EU, it was just above the $5 \%$ of the threshold. The same can be said of the CHP but in the negative direction. Once again, utilitarian concerns were positively associated with EU support. 
Model 3 measures indicators of support among the Alevi participants. Interestingly, the strongest coefficient (of all models) is the positive association for support for the EU from supporters of the AKP. Next in significance is the utility aggregate score, followed by support for the de facto regional and ethnic Kurdish DTP and then support for the CHP. Interestingly, among Alevi's, there was a strong negative association between fear of foreign threat and support for the EU. Religiosity was not a significant coefficient in any of the models.

In relation to our hypotheses set out above, the results bring both interesting areas of convergence and divergence from our expectations. Our hypothesis that utility would be an important indicator of EU support seems to be strongly confirmed. Across all models, it was a positively associated and significant variable. Furthermore, its salience among Alevis seems to be stronger than among the general populace.

Our hypotheses derived from the issues of feelings of national identity and fear of foreigners were both confirmed and disconfirmed, in part, by the results. The hypothesis that strong feeling of national identity would be negatively related to support for the EU turned out to be largely disconfirmed. Although the beta scores for this index in all the models were mildly negative, none were at all close to significance. The only point that might provide some confirmation of this is that supporters of the strongly nationalist MHP registered negative associations with EU membership in both models in which it was included as a variable. This could mean that the index was delineating a level of national identity that must be distinguished from the views of the supporters of the ultra-nationalist party (a likely possibility), or it could mean that the lack of support for the EU from MHP supporters could lie in other or additional issues distinct from that of simple nationalism, such as domestic political posturing by the party leadership.

That fear of foreign threat would be an indicator of negative support for the EU was certainly confirmed by the results from the models. As an index, it discriminated between support and lack of support for membership more effectively than the nationalism index. Thus, strong personal feelings of national attachment seem less an obstacle for the EU project than perspectives that focus on the identities of nonTurkish citizens. Interestingly enough, this relationship between fear of foreigners and lack of support for the EU appeared to be even stronger among Alevis. Furthermore, the hypothesis that religious views would not significantly impact one's perspective about EU membership among Turkish citizens was confirmed. It registered with high measures of insignificance in all the models, confirming what Kentmen (2008) noted in her study. The variable for religiosity used was, however, correlated strongly with supporters of the AKP (.390) and MHP (.216), ${ }^{15}$ which confirms most other studies determining a similar relationship.

The results also shed some interesting light on the question of non-dominant cultural groups' attitudes toward the EU. While Alevi identity was a powerful indicator of support for the EU, the same cannot be said for either the supporters of the de facto (and now defunct) ethno-nationalist DTP or those who spoke a dialect of Kurdish at home. Only Alevi supporters of the DTP seemed to be strongly related to support for membership. Among the non-Alevi population, support for the DTP tended toward negative attitudes toward the EU, surprisingly disconfirming that particular hypothesis.

Outside of the unexpected results regarding the de facto regional DTP, the other hypotheses predicting relationships between political parties and attitudes toward 
membership were confirmed. Support for the EU tended to be positive and significant for supporters of the current governing AKP, while support for the CHP was indeterminate, but when Alevis are removed, its negative coefficient approached significance $(p<.10)$. Support for the nationalist MHP was negatively associated with the dependent variable. Although Alevi participants tended not to vote for the AKP and showed tendencies to vote for parties associated with the left, the Alevis that did vote for the current governing party had the strongest beta scores associated with EU support.

\section{Discussion}

Although this study was relatively small in scope of number of surveys (just $<500$ total), perhaps one of the most interesting findings is that the salient factors influencing public opinion among Turkish citizens in general quite closely paralleled the determinants observed in much wider contexts. Just as Hooghe and Marks (2005) demonstrated from the results of their research, utilitarian concerns, identity and political affiliation are important factors influencing how EU membership is viewed in Turkey. In the present study, the determination of the salience of political factors (hitherto not systematically analysed in this fashion) along with initial results regarding non-dominant cultural group attitudes seems to be a significant contribution in addition to its confirmation of the significance of utilitarian concerns and fears of foreign encroachment.

In this period of Turkey's history, politics is very important; it is not surprising, therefore, for party affiliation to be such a strong determinant of support for the EU. Turkish society is experiencing numerous changes, of which membership in the EU would be a significant one, and the country stands at the threshold of a number of quite distinct trajectories, which are viewed in very different ways by various segments of the population. The polarizing behaviours of political elites have established deep cleavages that seem quite difficult to bridge. Within such an environment, how the EU question is appropriated into the political debate is an intriguing one. The question prompted by such results is whether or not parties are cueing the attitudes of their constituents or whether the voters are grouping themselves under the umbrellas of parties that align with their views of the EU.

We would propose that, in the current domestic political climate, there is strong reason to believe the former assertion - i.e. that it is indeed cueing. This research coupled with existing research seems to indicate that views toward the EU are shifting with time in conformity with the attitudes cued by the leaders of the parties. If one takes into account the study by Çarkoğlu (2003b), conducted months before the AKP came to power, the descriptive statistics indicate that the supporters of the CHP in 2002 were one of the strongest groups in favour of EU membership while supporters of the untested AKP registered as second to lowest among all the parties. That study also showed that religiosity was negatively related to support for the EU. Our study clearly indicates that when Alevis are removed from CHP supporters in Model 2, the coefficient becomes negative at a level approaching significance. A recent work by Hale and Özbudun (2010, 36) cites an unpublished study by Hakan Yilmaz that also shows that, from 2002 to 2006, the support for the EU among AKP supporters rose by $20 \%$ while it concurrently declined by $23 \%$ among CHP supporters. That the AKP party lead- 
ers have supported the EU project from the outset is no mystery (although their apparently waning enthusiasm has become a recent topic of debate), but the normal descriptions of their constituency suggest a population that, in most countries, would not strongly support membership in a European body. Correlations between religiosity and other variables and indices in this study show a significant relationship between this group and fear of foreign encroachment, strong national identity, support for the nationalist MHP and rightward positioning on the left-right self-placement, ${ }^{16}$ relationships that might normally anticipate a negative attitude toward the EU. The key off-setting variable could be argued to be this group's strong correlation with support for the AKP, the party most committed to the EU membership project. This seems to confirm a proposition by Dağ1 (2006) who argued that the AKP's shaping of their conservative constituency's attitude toward the west and the EU could be argued as one of the party's most important contributions to Turkish politics and society. Thus, political cueing could be argued to play an important role in the attitudes of Turkish citizens to the EU. However, such a conclusion also suggests that the party's apparent EUfatigue is also likely to be transmitted to their social support base.

Another interesting question arises from the divergence in results between Alevis and the proxies variables for Kurds in Turkey (mother tongue and support for the DTP), for which the general literature on minority group attitudes toward the EU would anticipate similar attitudes toward EU membership. Why Alevis seem to be more clearly supportive of the EU in this study, such that it seemed to override political affiliation, as compared to Kurds becomes an interesting question. While some studies, such as Çarkoğlu (2003b), have suggested a high amount of support among Kurds and those who support de facto regional parties of the southeast, in both his studies and this current one, when Kurdish identity placed as a variable in a regression model, the coefficients tend toward the negative, especially if one controls for Kurdish Alevis. The historical pattern of behaviour among Kurds in Turkey has consistently shown marked intra-group disagreement on significant political matters, including political party of choice; it is likely that such a divergence also exists in relation to the question of supporting or opposing EU membership. This study is not comprehensive enough to generate certain conclusions, but the strong divergence among these Alevi and Kurdish participants warrants further attention in future studies. If further studies are conducted, it would likely be fruitful to also measure differences based on intra-group distinctions similar to the study by Campbell (2004), measuring differences in political activism among various Christian denominations in the USA. This might be particularly interesting among Alevis.

This research also seems to indicate that, to the extent that attitudes are shaped from political cueing by party leaders, current attitudes among various party supporters could again change depending on the domestic and international political climate. Will the party of Atatürk, the CHP, once again face more determinedly 'West' as its founder once did? Has the AKP changed the values and attitudes of many of the conservatives in Turkey forever, or is this too a mirage of a contingent context? Will the widely disseminated views in Turkey of xenophobes in Europe who are against Turks and Turkish membership in the EU eventually overcome Turkish citizens' strong dispositions toward utilitarian and functional interests? The answers to these will only be determined with the passing of time. 


\section{Acknowledgements}

We would like to thank Burcu Kamarlı, Zeki Sarıil, Torsten Selck, Emine Bademci, Gökhan Güler and Ayşenur Kılıç among others for their valuable contributions at various stages of this research.

\section{Notes}

1. Scholars range in their estimates anywhere from 10 to $25 \%$. Poyraz (2005) notes that Alevis themselves have claimed $30-40 \%$.

2. For an interesting study analyzing how other national parties in Europe take positions on Turkey's accession based on such strategic and structural factors rather than ideology, see Chatzistavrou (2010).

3. The authors have intentionally chose to avoid the term 'minority' for several reasons though this term could (and has) been widely appropriated in discussions about Kurds and Alevis. While it is true that the Turkish state does not formally recognize these groups as minorities, it is also true that many members of these groups, particularly among Alevis, do not appreciate being identified as a 'minority' either. Stemming from policies employed toward the end of the Ottoman Empire, the designation of 'minority' has become an expression that results in further marginalization and isolation of the targeted group. Thus, the apparent 'benefits' of minority status are seen as far inferior to the cost of being socially labeled as a 'second-class citizen' and 'potential traitor'. For this reason, the authors felt that the expression 'non-dominant' cultural groups/communities would suffice.

4. There are a number of interesting and detailed studies regarding the particular case and developments regarding Turkey's EU relations. For a broader picture of the individual case, see the collected works of Çarkoğlu and Rubin (2003) and Uğur and Canefe (2004).

5. For a number of excellent studies on Alevis, see the collected work by Olsson, Özdalga, and Raudvere (2003) and the ethnographic study by Shankland (2003).

6. As indicated by Melikoff $(2003,6)$, the distinction between the groups was more in regard to social practices rather than belief. While the Bektas community tended to engage in a more sedentary life and organized ritualized religious practice centered around lodges (tekke), the Kızllbaș tended to be more nomadic and flexible in religious practice, infusing local folklore into existing religious legends.

7. Sometimes referred to as Selim, the Grim by English historians or Yavuz Sultan Selim in Turkish.

8. For a broader survey and debate on the Kurds in Turkey, see Kirișçi and Winrow (1997), Barkey and Fuller (1998), McDowall (2004), Heper (2007), and in Turkish, Yeğen (1999).

9. For more about the composition of these elites, see Zürcher (2005).

10. Approximately $20 \%$ of Alevis are Kurdish, see Poyraz (2005).

11. The parties formed by these political elites have been regularly closed down by the Constitutional Court. They have existed as the People's Labor Party (Halkın Emek Partisi), the Democracy Party (Demokrasi Partisi), the People's Democracy Party (HADEP), the Democratic People's Party (Demokratik Halk Partisi), the Democratic Society Party (DTP), and, as of 2009, the Peace and Democracy Party (BDP).

12. The DTP was closed in December 2009 by the Constitutional Court for 'undemocratic' behavior and support for terrorism.

13. This is true for the time during which the survey was distributed (see Note 8).

14. Turkish Communist Party.

15. Two-tailed Pearson coefficient with a significance of .000 for both.

16. Two-tailed Pearson coefficients, .339, .327, .216, and .322 respectively all with .000 significance.

\section{Notes on contributors}

F. Michael Wuthrich is a Lecturer at the University of Kansas in the Applied English Center and a Courtesy Researcher in the Department of Political Science. He completed his PhD in the department of political science at Bilkent University in June 2011, and his research interests include political parties, party systems, electoral behavior, and nationalism, 
particularly as these relate to Turkey and the Middle East. He has published in Turkish Studies and has a forthcoming article in the Middle East Journal.

M. Murat Ardağ is a $\mathrm{PhD}$ candidate in the Political Science Department at Bilkent University. His research interests are nationalism and Turkish politics, political psychology, conceptions of culture and politics, and social cognition of politics.

Deniz Uğur is a PhD student in the Political Science Department at Bilkent University. His research interests center on religious and cultural minorities in Turkey, particularly Alevis and Suriyanis.

\section{References}

Aringberg-Laanatza, M. 2003. Alevis in Turkey - Alawites in Syria: Similarities and differences. In Alevi identity, 2nd ed., ed. T. Olsson, E. Özdalga, and C. Raudvere, 151-65. Istanbul: Swedish Research Institute.

Barkey, H., and G. Fuller. 1998. Turkey's Kurdish question. Lanham, MD: Rowman \& Littlefield.

Campbell, D.E. 2004. Acts of faith: Churches and political engagement. Political Behavior 26, no. 2: $155-80$.

Carey, S. 2002. Undivided loyalties: Is national identity an obstacle to European integration? European Union Politics 3, no. 4: 387-413.

Chatzistavrou, F. 2010. Early preferences of national political parties in the EU for Turkey's accession. Southeast European and Black Sea Studies 10, no. 4: 385-409.

Christin, T., and H. Trechsel. 2002. Joining the EU? Explaining public opinion in Switzerland European Union Politics 3, no. 4: 415-43.

Çağaptay, S. 2002. Reconfiguring the Turkish nation in the 1930s. Nationalism and Ethnic Politics 8, no. 2: 67-82.

Çarkoğlu, A. 2003a. Conclusion. In Turkey and the European Union: Domestic politics, economic integration and international dynamics, ed. A. Çarkoğlu and B. Rubin, 245-52. London: Frank Cass.

Çarkoğlu, A. 2003b. Who wants full membership? Characteristics of Turkish public support for EU membership. Turkish Studies 4, no. 1: 171-94.

Çarkoğlu, A. 2004. Societal perceptions of Turkey's EU membership: Causes and consequences of support for EU membership. In Turkey and European integration: Accession prospects and issues, ed. M. Uğur and N. Canefe, 19-45. London: Routledge.

Çarkoğlu, A. 2005. Political preferences of the Turkish electorate: Reflections of an Alevi-Sunni cleavage. Turkish Studies 6, no. 2: 273-92.

Çarkoğlu, A. 2006. The new generation pro-Islamists in Turkey. In The emergence of a new Turkey: Democracy and the AK Parti, ed. H. Yavuz, 160-81. Salt Lake City, UT: University of Utah Press.

Çarkoğlu, A., and B. Rubin. 2003. Turkey and the European Union: Domestic politics, economic integration and international dynamics. London: Frank Cass.

Dağı, İ. 2006. The Justice and Development Party: Identity, politics, and human rights discourse in the search for security and legitimacy. In The emergence of a new Turkey: Democracy and the AK Parti, ed. H. Yavuz, 88-106. Salt Lake City, UT: University of Utah Press.

Dorronsoro, G., and N. Watts. 2009. Toward Kurdish distinctiveness in electoral politics: The 1977 local elections in Diyarbakir. International Journal of Middle East Studies 41: 457-78.

Duran, B. 1998. Approaching the Kurdish question via Adil düzen: An Islamist formula of the welfare party for ethnic coexistence. Journal of Muslim Minority Affairs 18, no. 1: $111-28$.

Erman, T., and E. Göker. 2000. Alevi politics in contemporary Turkey. Middle Eastern Studies 36, no. 4: 99-118.

Gabel, M. 1998. Public support for European Integration: An empirical test of five theories. The Journal of Politics 60, no. 2: 333-54. 
Gabel, M., and K. Scheve. 2007. Mixed messages: Party dissent and mass opinion on European integration. European Union Politics 8, no. 1: 37-59.

Garry, J., and J. Tilley. 2009. The macroeconomic factors conditioning the impact of identity on attitudes towards the EU. European Union Politics 10, no. 3: 361-79.

Goodwin, J. 1998. Lords of the horizons: A history of the Ottoman Empire. London: Vintage.

Grigoriadis, I. 2006. Political participation of Turkey's Kurds and Alevis: A challenge for Turkey's democratic consolidation. Southeast European and Black Sea Studies 6, no. 4: 445-61.

Grigoriadis, I. 2009. Trials of Europeanization: Turkish political culture and the European Union. New York, NY: Palgrave Macmillan.

Gülmez, S. 2008. The EU policy of the Republican People's Party: An inquiry on the opposition party and Euro-Skepticism in Turkey. Turkish Studies 9, no. 3: 423-36.

Hale, W., and E. Özbudun. 2010. Islamism, democracy and liberalism in Turkey. London: Routledge.

Heper, M. 2007. The State and Kurds in Turkey: The question of assimilation. New York, NY: Palgrave Macmillan.

Hooghe, L., and G. Marks. 2005. Calculation, community, and cues. European Union Politics 6, no. 4: 419-43.

Jolly, S.K. 2007. The europhile fringe? Regionalist party support for the European Union. European Union Politics 8, no. 1: 109-30.

Kadioğlu, A. 1996. The paradoxes of Turkish nationalism and the construction of official identity. In Turkey: Identity, democracy, politics, ed. S. Kedourie, 177-93. New York, NY: Routledge.

Kalaycioğlu, E. 2008. Attitudinal orientation to party organizations in Turkey in the 2000s. Turkish Studies 9, no. 2: 297-316.

Kentmen, Ç. 2008. Determinants of support for EU membership in Turkey. European Union Politics 9, no. 4: 487-510.

Kirișçi, K., and G. Winrow. 1997. The Kurdish question and Turkey. New York, NY: Routledge.

Mattila, M., and T. Raunio. 2006. Cautious voters - supportive parties: Opinion congruence between voters and parties on the EU dimension. European Union Politics 7, no. 4: 427-49.

McDowall, D. 2004. A modern history of the Kurds. 3rd ed. London: IB Tauris.

McLaren, L.M. 2002. Public support for the European Union: Cost/benefit analysis or perceived cultural threat? The Journal of Politics 64, no. 2: 551-66.

Melikoff, I. 2003. Bektashi/Kızılbaș: Historical bipartition and Its consequences. In Alevi identity, 2nd ed., ed. T. Olsson, E. Özdalga, and C. Raudvere, 1-7. Istanbul: Swedish Research Institute.

Olsson, T., E. Özdalga, and C. Raudvere. 2003. Alevi identity. 2nd ed. Istanbul: Swedish Research Institute.

Poyraz, B. 2005. The Turkish State and Alevis: Changing parameters of an uneasy relationship. Middle Eastern Studies 41, no. 4: 503-16.

Ray, L. 2003. When parties matter: The conditional influence of party positions on voter opinions about European integration. The Journal of Politics 65, no. 4: 978-94.

Shankland, D. 2003. Alevis in Turkey: The emergence of a Secular Islamic tradition. London: Routledge.

Steenbergen, M.R., E. Edwards, and C. de Vries. 2007. Who's cueing whom? Mass-elite linkages and the future of European integration. European Union Politics 8, no. 1: $13-35$.

Uğur, M., and N. Canefe. 2004. Turkey and European integration: Accession prospects and issues. London: Routledge.

Ulusoy, K. 2009. The changing challenge to Europeanization to politics and governance in Turkey. International Political Science Review 30, no. 4: 363-84.

Wuthrich, F.M. 2011. Paradigms and dynamic change in the Turkish party system. Bilkent University, Unpublished dissertation.

Yalçın-Heckmann, L. 1990. Kurdish tribal organisations and local political processes. In Turkish state, Turkish society, ed. A. Finkel and N. Sirman, 289-312. London: Routledge. 
Yeğen, M. 1999. Devlet Söyleminde Kürt Sorunu [The Kurdish question in state discourse]. Istanbul: İletișim Yayınları.

Yeğen, M. 2009. 'Prospective-Turks' or 'Pseudo-Citizens:' Kurds in Turkey. Middle East Journal 63, no. 4: 597-615.

Yilmaz, H. 2011. Euroscepticism in Turkey: Parties, elites, and public opinion. South European Society and Politics 16, no. 1: 185-208.

Zürcher, E.J. 2005. How Europeans adopted Anatolia and created Turkey. European Review 13, no. 3: 379-94. 